Terbit online pada laman web jurnal : http://e-journal.sastra-unes.com/index.php/JILP

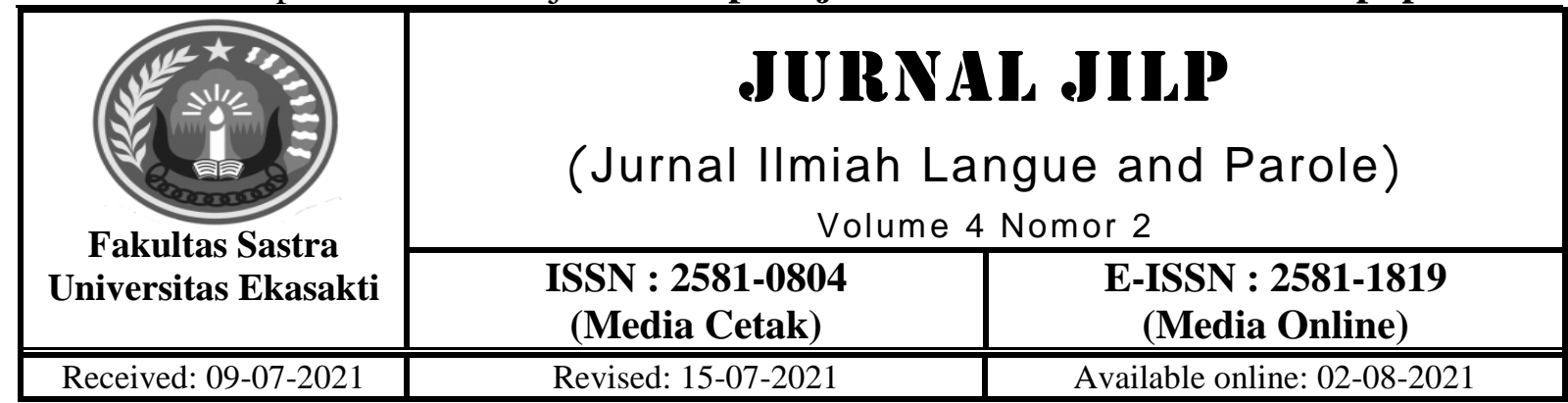

\title{
STYLISTICS ANALYSIS IN LITERATURE OF FIGURATIVE LANGUAGE USED IN BLACK LIVES MATTER COMMUNITY'S POEMS
}

\author{
Dedi Efendi \\ English Literature Program Faculty of Language Muara Bungo University, efendidedi1986@gmail.com
}

\begin{abstract}
This research analyzed about figurative language and social values in three poems of Black Live Matter (BLM) community's poem in America. The purposes of this research are to describe the kinds of figurative language and social values in three poems of BLM community's poem. In this research, the writer used the descriptive qualitative method and used theory of figurative language by Perrine (1992) and theory of social values by Amir in Sukatman (1991). Data are explained by find the meaning and described them based on the kinds of figurative language through four procedure, they are: identifying, classiying, analyzing and making the conclusion from the data. The result of this research are the writer found about 19 data of figurative language of the poems. Hyperbole is the dominant kind of figurative language in those three poems, because hyperbole is the appropriate of figurative language for BLM's proponents for looking for help. Beside, social values also found in these poems, the most dominant social value in these poems is social value of humanity. Humanity is one of the biggest issue for black people in United State of America.
\end{abstract}

Keywords: Figurative language analysis, Black Lives Matter's poems

(C) 2021Jurnal JILP

\section{INTRODUCTION}

Poetry is type of literature that written by a poet which has aesthetic and deepest meaning. The writer of a poetry called as a poet. A poet usually writes a poetry to expressing his or her various emotions and feeling. A poet uses to expressed his or her modes in a poem by variety of technique. Barnet (1961:5) States that poetry can be thought of as a verbal, written art form that uses a heightened sense of language to convey experience, feeling, or modes of consciousness. Every people has their own way to convey their experience and the poets use poetry for cover them.
Poetry written to be enjoyed because a poet usually uses supporting elements to enrich the meaning and bring the readers imagination to his or her minds in poetry. To get great poetry, a poet has to creat a poem by putting some supporting elements that is called by intrinsic elements such as figure of speech, rhyme, rhythm, imagery and tone to enrich the meaning and make the every reader feels easy to understand what the poet want to say in his or her poem. Gill in Efendi (2010) also said that the poin about poetry and the other form of literature is that choice of words and elements inside used

Jurnal JILP (Jurnal Ilmiah Langue and Parole) Vol.4No. 2 (2021) ISSN : 2581-0804

This work is licensed under a Creative Commons Attribution-NonCommercial 4.0 International License. 
by the author. It means that a literary work can called as a poem if the author put some instrinsic elements such as figurative language, rhyme, rhythm, imagery and tone in it.

Figurative Language is a language that's a poet uses to create an image, association, or other effect in the mind of the listener or reader that goes beyond the literal meaning or expected use of the words involved. According to Perriene (1992:679) states that figurative language is a language that does not use language in general or is another way of saying something other than the usual way or in this case the language used. While Abrams (1999:96) said that figurative language is a habit of speculating in understanding a language as an understanding of standard sentencesor result. For example, Randy Batiquin put some of figurative language through his poem with title Let Me to describe his feeling about love to someone that he met in his life eventhough he can tell his feeling directly to the girl that he love so much. Besides, figure of speech as one of literary element, it creates the sense or power to describe things in unique ways. The readers or literary lovers can explore the words in fiction or non fiction which are expressed by the author.

In this research, the writer is interested in finding and analyzing about the experiences and feeling of the author through his or her poems. The simple reason why the writer is interested to analyze the poems is because the poems created by Black Lives Matter proponents. Black Lives Matter is an organized movement in the United States, United Kingdom and Canada to advocating for nonviolent civil disobedience in protest against incidents of police brutality against African-American people.

In 2013, three radical Black organizers Alicia Garza, Patrisse Cullors, and Opal Tometi - created a Black-centered political will and movement building project called \#BlackLivesMatter. It was a response to the acquittal of Trayvon Martin's murderer, George Zimmerman. The movement began with the use of the hashtag \#BlackLivesMatter on social media after the shooting death of AfricanAmerican teen Trayvon Martin in February 2012. In the last some years we also found some information in some countries especially in USA that there were some accidents about racism, white people kill the black people. Some black people convey their emotions by many ways, some of them are protest the insident about the death of some black people killed by white people through demontration and another way was the BLM proponents creat some poems with deepest protest.

Based on blacklivesmatter.com there are more than 20 protest poems created by BLM proponents and the writer would like to anylize four poems of them because those poem are have the deepest meaning for the BLM proponents, they are: Mother Africa! May I Return? Dear Emmet Till and My Sweet Boy. The poems were made around 2012 to 2019 after the shooting death of African-American teen Trayvon Martin in February 2012. In genarlly the poems contain by alot of messages and protest against the deaths of numerous other African Americans by police actions.

The main reason why the writer is interested in analyzing the poems is because there are many figurative language with deepest meaning found in those poems and each meaning of the poem has some purpose for conveying the social values for the white people, especially for the goverment of United State of America. For example, the first time the writer read one of those poems with title Mother Africa, May I Return? The writer read the unique bait, it is the first line of the first stanza of the poem:

\section{Mother Africa, can you hear my calls?} falls.

I'm shouting out to you as my universe hurting.

These chains on my neck and hands are Left without any keys.

If the readers read the first line of poem above Mother Africa, can you hear my calls? directly, the readers will not understand what the author want to says in his poem. But base on Barnet statement above that poetry is a verbal, written art form that uses a heightened sense of language to convey experience, feeling, or modes of consciousness, so the writer includes the sentence Mother Africa, can you hear my calls? into kind of figurative language, it is Personification.

Personification is giving the attributes of a human being to an animal, an object, or a concept (Perrine, 1992: 64). While according to encyclopedia, personification is a figure that 
endows, object, animal, idea or an abstraction with human form character or sensibility. The words Mother Africa is not a human, it can not hear a phone call from human, it is an object (a country) and it has human characteristic, the author want to says his sadness, he got many unfairness and racism when he live in America. Based on Amir in Sukatman mention that a person who lives and die in a country, its can be called as loyalty of social value. So, the social value show in line of the poems above is writer conclude as social value of loyalty.

Black Live Matter movement organization has many interesting poems about their protest

\section{RESEARCH METHODS}

Method is a way or a strategy to understanding of realities, steps of systematic to analyzed of the problem. In this research the writer uses qualitative method for analysis. According to Strauss and Corbin (1998:11) state that qualitative research is achieved not by means of quantification or statistical technique. It can give complex detail about particular phenomena which are difficult to be expressed with quantitative method.

This adding opinion by Vanderstoep and Johnson (2009:167), this method focuses on cultural, social, personal identity and its goal is more descriptive than predictive. Moreover, Bodgan and Biklen (1982:28) who state that qualitative research is desriptive; the collected the data is in form of words as picture rather than numbers. Therefore, from some definition above, it can be concluded that qualitative research will

\section{RESULTS AND DISCUSSION}

In this research, the data is presented in writing. The writer uses informal method to present the research because the data that analyze in the form of word and phrase based on the finding. The writer presents as an introduction outlining the background of the problem that relates with figurative language and cosial values in Black Live Matter (BLM) community's poems. Then, the writers has limit to discuss against unfearness by white people to black people in America and all of the poems are contain with great figurative language. Besides, BLM community's poem are another way of black people choose to protest about discrimation in United State, these poems also tell us about how to respect each other even we have many differences like different skin, different culture, etc. From all of reasons above, the writer interest to analyze this research with entitle: Figurative Language Analysis on Black Lives Matter (BLM) Community's Poems.

be in the form of sentence, rather than statistic and numbers to comprehend phenomenon.

In this research, the writer uses some ways to get information as the data in this research. So, the writer classifies the source of the data into two categories, namely primary data and secondary data. Primary data is the source of data that it is most important sources in order to get information that the writer wants to be analyzed in this research. The primary data in this research are some words, phrases, lines or stanza of the poems from Black Lives Matter movement organization. While, the secondary data is the supporting information that can help the writer in analyzing this poems. The writer takes the secondary data from other sources to support this research, such as journal, etc.

It is clear that, descriptive qualitative method is a method that usually used by the other writers in doing this library research.

only about several problems through two research questions:

1. What kinds of figurative language found in Black Lives Matter poems?

2. How do figurative language convey the social values in Black Live Matter poems?

\section{DISCUSSION}

Jurnal JILP (Jurnal Ilmiah Langue and Parole) Vol. 4No. 2 (2021) ISSN : 2581-0804

This work is licensed under a Creative Commons Attribution-NonCommercial 4.0 International License. 
The writer $\mathrm{w} \quad$ ill present the results of the data analysis that describe the kinds of figurative language found in Black Lives Matter (BLM) community's poems and also explain how do figurative language convey the social values through the poems. The display of the data was done formally by giving the description of the figurative language that has found in Black Lives Matter poems.

3.1 Kinds and Meaning of Figurative Language Found in Black Lives Matter Community's Poems. May I return?

3.1.1 Poem Analysis: Mother Africa, Mother Africa, May I return? poem is one of the poem that created by Black Lives Matter proponent, the poem created by Dr. Saundra Collins on 2016. The purpose of the poem is the author wants to protest any kind of violences by white poeple to the balck people African-American in United State of America. The poem is divided into 5 stanza, in stanza 1 to 4 diveded into four lines and only 3 lines for stanza 5. This poem is tells the readers about another hope of Black People in United State of Amarica, they hope for another way to refuse of any kind of racism, violence and unfairness from white poeple to black people in that country.

\section{Mother Africa, May I return?}

Mother Africa, can you hear my calls ? falls.

I'm shouting out to you as my universe hurting.

These chains on my neck and hands are

Left without any keys.

I see other people chained just like me.

Heading for boats on the forbidden sea.

Mother Africa, can you hear my call?

I am being stolen

Forced far away from home. I am

Lost. In the dark. I can not see.

Vomit, blood, and dead bodies cover me .

Mother Africa where are you?

Please come save me from this misery.

For yet, I will be sold as a slave .

Over 500 years past, I still call for you.

Why have you stopped looking for me?
Mother Africa, Are you still waiting for

Me to return to your beloved homeland?!

Will you welcome me with open arms ?

\subsubsection{Personification}

Datum 1: Mother Africa, can you hear my calls?

The first stanza of the first line, Mother Africa, can you hear my calls ? is the first figurative language set by author in her poem. This line means that the author (Dr. Saundra Collins) is begins looking for a help for her suffering to another country and she hope that she can come back to the country of Africa. She feels that she did not accepted in United State just because of his black skin, she got many kinds of violences from white people.

The word Mother for a country Africa is the writer called as Personification. Based on Perrine statement that Personification is giving the attributes of a human being to an animal, an object, or a concept (Perrine, 1992: 64). Africa is non human, it is an object but it has a characteristic of human who could protect her son or daugther. The author is feels that maybe she will be safe if she come back to th at country.

\section{Datum 2: Why have you stopped looking for me?}

The second personifications that writer found in this poem is can be seen on line 4 stanza 4 Why have you stopped looking for me?. In this line, the author asking a question to Mother Africa, the question is why she (Mother Africa) stop looking for her but the author still need some help from Mother Africa to safe her from her suffering.

The line Why have you stopped looking for me? is the writer categorize as personification, because if we find the meaning of the line, the author hope that her perfunctory country looking for her, but as the writer explain before the country of Africa is not a human so it can not do what human can do like looking for its people.

Datum 3: Mother Africa, Are you still waiting for Me to return to your beloved homeland?!

The third personifications that writer found in Mother Africa, May I return? poem are in the first and second lines of stanza 5, they are; Mother Africa, Are you still waiting for

Jurnal JILP (Jurnal Ilmiah Langue and Parole) Vol.4No. 2 (2021) ISSN : 2581-0804

This work is licensed under a Creative Commons Attribution-NonCommercial 4.0 International License. 
Me to return to your beloved homeland?!. In these lines the author still use personification to express her feeling and emotion to protest about the death of balck people in America.

Another human characteristic which is author set in these lines poem is the word waiting. Author is seem like asking another question, is country of Africa still waiting for black people to go back to that country for helping them. Waiting is a word that usually use by human in daily activity and daily coversation. Another things like an object, animal, etc. are do not understand what waiting is, so the writer put these lines into personification.

Datum 4: Will you welcome me with open arms?

The last personification that the writer found in this poem is in the last line of the last stanza (stanza 5) of the poem, it is; Will you welcome me with open arms? in this line, the author said that even she was born and grew up in great country like United State of America, she still hope that the country of Africa is welcome for them to come back to that country. She think that come back to Africa is the best choice for her and another black people than still live in America but they got many unfairness, racism and suffering from white people.

The line Will you welcome me with open arms ? is the last hope that author want from Africa in this poem. Open arm is also human characteristic. In daily live of human, open arm means that we are welcome to another people if they need some help, we helping each other in a social life. Open arm can't do by a country, the country has no arm like human, so the writer conclude that this line is a kind of personification.

\subsubsection{Hyperbole}

Datum 5: I'm shouting out to you as my universe falls.

Hyperbole is one of figurative language that writer found in this Black Lives Matter community's poem. The first hyperbole is can be seen in the second line of the first stanza of the poem, it is I'm shouting out to you as my universe falls. In this line the author wants to say to the country of Africa that she shouting out for some help of her suffering like universe falls down. The author is really need some help from it country.
The line I'm shouting out to you as my universe falls is categorize as hyperbole because the author put an overstatement or exaggeration for her condition in United State of America. This explanation supported by Perrine (1992:101). Overstatement or hyperbole is simply exaggeration but exaggeration in the service of truth . Overstatement may be used with a variety of effects. It may be humorous or grave, fanciful or restrained, convincing or unconvincing.

The author is wants to tell to all of the readers and especially the government of United State that the black people really feel suffering when live in that country. They have no more idea where they can go for run away from unfairness and racism that they got.

Datum 6: These chains on my neck and hands are hurting.

The second hyperbole that the writer found in the poem is in line 3 of the first stanza, it is These chains on my neck and hands are hurting. In this line the author try to explain her condition by giving the illustration. She illustrate a conditon that she and another black people in Unitied State of America got some chains in their neck and hands. The author would like to say to whole world especially country of Africa that how suffer they are in this country.

In this line, the writer is also puts it into kind of hyperbole figurative language because the line These chains on my neck and hands are hurting contain by words chain on my neck. As we know that, nowadays there were no more black people live with a chains on their neck and hands. But, the author explain it by uses overstatement in her poem.

\section{Datum 7: Forced far away from home. I am \\ Lost. In the dark. I can not see. Vomit, blood, and dead bodies cover me.}

In this three lines of the third stanza of the Mother Africa, May I return? poem also contain by hyperbole figurative language, it is I am Lost. In the dark. I can not see. Vomit, blood, and dead bodies cover me. In the lines, the author is would like to say there were some balck people died killed by white people in America, especially by policeman. The author would like to explain that their anxiety eventhough she and another balck people has no fault.

Jurnal JILP (Jurnal Ilmiah Langue and Parole) Vol.4No. 2 (2021) ISSN : 2581-0804

This work is licensed under a Creative Commons Attribution-NonCommercial 4.0 International License. 
The line I am Lost. In the dark. I can not see. Vomit, blood, and dead bodies cover me include into hyperbole because actually the black people in United State of America is not lost, they do not live in the dark in leterally meaning, they do not live cover by dead bodies but they only got some unfairness and bad treatment from America's government.

Datum 8: Over 500 years past, I still call for you.

The last hyperbole that the writer found in this Black Lives Matter (BLM) community's poem is in the third line of the fourth stanza, it is Over 500 years past, I still call for you. In this line the author would like to tells to the readers of the poem that she and maybe another black people in America actually has a planning to come back to the country of Africa since a long time ago, since they got very bad treatment from the United State of America's government.

The line Over 500 years past, I still call for you is contain by an exaggeration statement because in recently live there is no more a human can live untill 500 years old. But, in this poem the author would like to protest that this bad treatment from their government was happened since long time ago and now it still happen to them.

They got careless from the government, they got difficulty to find better live in this country, they can not got better job. In other wise, white people can live by happy and got all of facilities, easy to find a better job with high salaries.

\subsubsection{Simile}

Datum 9: I'm shouting out to you as my universe falls.

Perrine, (1992: 61). Said that Simile is a means of comparing things that are essentially unlike. In simile, the comparison is expressed by the use of some words or phrases, such as like, as, than, similar to, resembles, or seems. In this poem the first simile that the witer found is in the second line of the first stanza, it is I'm shouting out to you as my universe falls. In this line, the author would like to compare her shouting out to country of Africa with universe falls. The author look like want to tells to Africa that she is in a big trauble in this country. So, the witer choose this line as categorize of simile figurative language.

\section{Datum 10: I see other people chained just like me.}

Another simile that writer found in the Mother Africa, May I return? poem is can be seen in the first line of the second stanza (stanza 2 ), it is the line of I see other people chained just like me. Here, the writer try to describe that another black people have the same suffering in this country just like herself. So, she try to explain it by comparing another people pain and hers. Based on the analysis of the data above, the writer make a conclusion that it line is categorize as simile figurative language.

Datum 11: For yet, I will be sold as a slave.

The last simile in this poem that the writer found is in line two of fourth stanza, it is For yet, I will be sold as a slave. In this line the author also use simile figurative language to camparing her life condition. The government bad treatment for black people in United State of America just like a thing for sale. It can be valuale if the thing was sold. Comparing a thing for sale as a slave, can be concluded as simile in figurative language.

\subsubsection{Symbol}

\section{Datum 12: These chains on my neck and hands are hurting.}

In this great poem, the writer also found another figurative language, it si Symbol. Symbol can be seen in the third line of the first stanza, it is the line of These chains on my neck and hands are hurting. A symbol may be roughly defined as something that means more than what it is (Perrine, 1992: 80). It means that a symbol uses a word or phrase which is familiar in society and has one meaning. Based on Perrine explaination above, the writer conclude that the word Chains in line These chains on my neck and hands are hurting is categorize as symbol. It is a symbol for how suffer, how bad the treatment that black people got from government of United State of America.

\subsubsection{Poem Analysis: Dear Emmett Till}

Dear Emmet Till poem is about Emmet Louis Till's brutal death. This poem created by Marilyn Nelson. The poem tells about 14 years old girl Till was visiting relatives in a small Mississippi town when he was accused of giving a white woman a "wolf whistle" outside a market. The husband of the woman and his half-

Jurnal JILP (Jurnal Ilmiah Langue and Parole) Vol.4No. 2 (2021) ISSN : 2581-0804

This work is licensed under a Creative Commons Attribution-NonCommercial 4.0 International License. 
brother pulled beautiful Till from the house where he was staying, drove him to the banks of the Tallahatchie River and shot him in the head. Despite eyewitness testimony, an all-white jury acquitted the two men of murder. Outrage over Till's death helped to mobilize the civil rights movement. Dear Emmit Till poem is divided into 10 stanzas, some stanzas has the same amount of line and other different amount.

\section{Dear Emmett Till}

I hear it was the whistling towards a white woman,

that got you killed, face beaten in like a castrated mummy.

They stopped you because they did not want to take the blame.

Oh! how they killed you because they hated themselves,

used a lie to send you to your grave in the most horrible way.

Blood stains the Coliseum doors.

Now history repeats, everyone getting killed like Till.

Dead Black bodies dropping down on the streets.

Shout all of their names 3 times!

They were innocent Black people, but 5-0 thought otherwise.

Police took away precious black lives of men, women, and children.

I know I'm guilty of it too, but not like them.

Stop the killing! Stop the racism! Freeze!

Black people are no longer enslaved,

We no longer wear those chains just to be painted gold.

Now once upon a time not too long ago,

A nigga like myself had to strong arm a hoe.

Hold your golden-black crown high

Black woman

Black woman

What do you see when you look in the mirror?

Do you see the strength

and heart of the warrior Afrekete?

Is your head held up high,

for a crown to rest?

And be dubbed black queen, mother of life, educator of black intelligence

Do you see your dark skin as it dances

and befriends the night,

kisses the sun and

absorbs black power day in and day out?

Do you see those wide hips, big bust,

big butt and big lips?

Never will you say that those precious

gifts

from descendant Saartjie Baartman are a

curse

Black woman

Black woman

what do you see when you look at you

Lookup!

Lookup I say.

See that melanin on fleek,

that no one would dare to compete with.

Black woman do you see us?

Ancestors who stand before you,

behind you and beside you.

Give birth to a Black nation

Do you see that within the mirror?

The blood and shadows of a warrior queen.

\subsubsection{Simile}

Datum 13: I hear it was the whistling towards a white woman, that got you killed, face beaten in like a castrated mummy.

The first figurative language that the writer found in Dear Emmet Till poem is simile, it is can be seen in the second line of the poem that got you killed, face beaten in like a castrated mummy. Here in this line, the author explain by detail how Emmet Till died at that bad day. She got killed by unknown white people. She got beaten face like a castrated mummy. When the author comparing face beaten like a castrated mummy, the writer called it as one of figurative language in a poem, it is simile. Support by Perrine (1992: 61) said that comparing things that are essentially unlike. In simile, the comparison is expressed by the use of some words or phrases, such as like, as, than, similar to, resembles, or seems. 


\subsubsection{Hyperbole}

\section{Datum 14: Blood stains the Coliseum doors.}

Hyperbole figurative language also found in this Dear Emmet Till poem. The hyperbole word is clearly appear on Blood stains the Coliseum doors line (line 6) of the poem. Here the author try to describe that so much blood came out from Emmet Till, even the blood could be stain the coliseum doors. This is the horrible accident happened ever, but the blood of the girl actually can not stain the coliseum doors. So, the use of overstatement in this line could be conclude as one of figurative language in a poem, it is hyperbole.

\section{Datum 15: kisses the sun and and day out? absorbs black power day in}

The last hyperbole in this poem is completely found in stanza 6 , it is in line 4 kisses the sun and absorbs black power day in and day out?. The writer called these lines as hyperbole is because no body in this world can kiss the sun but in this poem the author try to describe his braveness for every black people to fight for unfairnes, racism and bad treatment by white people. Kiss the sun in the line is one of exaggeration of statement and it is not the literally meaning in a poem.

\subsubsection{Symbol}

Datum 16: Stop the killing! Stop the racism! Freeze! enslaved, Black people are no longer We no longer wear those chains just to be painted gold.

Some of figurative language of symbols also found in this Black Lives matter (BLM) poem by the writer. The first symbol in the poem is can be seen on line 3 of the third stanza, it is We no longer wear those chains just to be painted gold. In this line the reader can feels the symbol by understanding of the line deeply, it is the word chain. A chain is a symbol of bad treatment of United State of America gonernment.

Datum 17: A nigga like myself had to strong arm a hoe. Hold
crown high

The second symbol that writer found in Dear Emmet Till poem is in line 6 but still in stanza 6, it is A nigga like myself had to strong arm a hoe. The word that categorize as a symbol is strong arm. Strong arm in this line means that black people have to brave to face any kind of problem in America regarding racism, unfairness and bad treatment from white people. Black people have to survive for their life and they need to tell to all of white people that black is beautiful, black people is no longer anslave.

\subsubsection{Poem Analysis: My Sweet Boy}

My Sweet Boy poem is a poem created by Tanya Parker in 2020. The poem created to react for a brutal accident to George Floyd's dead. As we know that on May 25, 2020, George Floyd, a 46 year old black American man, was killed in Minneapolis, Minnesota, during an arrest for allegedly using a counterfeit bill. Derek Chauvin, a white police officer, knelt on Floyd's neck for almost eight minutes, while Floyd was handcuffed and lying face down, begging for his life and repeatedly saying "I can't breathe". Officers J. Alexander Kueng and Thomas Lane further restrained Floyd, while officer Tou Thao prevented bystanders from intervening. During the final two minutes, Floyd was motionless and had no pulse. The following day, after videos made by witnesses and security cameras became public, all four officers were fired. Two autopsies found Floyd's death to be a homicide.

\section{My Sweet Boy \\ By Tanya Parker}

Momma, Momma

Send the angels

It's my neck

\section{My Sweet Boy}

Dusk is about to set

Nine months, nine minutes

Can't cry 'cause I know

what's to come next

\section{All of Heaven awaits you}

a few more minutes

my sweet boy,

then no more memory

my sweet boy.

\subsubsection{Hyperbole}

Datum 18: Momma, Momma 


\section{Send the angels}

In the last poem this research, the writer found some figurative laguange of the poem. The first figurative language is hyperbole that can be seen on the first and second line of the first stanza, it is Momma, Momma Send the angels. The author would like to says that the victim (George Floyd) need a miracle for his condition. He can not breath because of his neck was kneeling by a white policeman.

The sentence of Momma Send the angels is categorize as hyperbole because we know there is no body in this world can order for an angel to help a human. It is an overstatement by the author in her poem to react the policeman do the black man.

\section{Datum 19: All of Heaven awaits you}

The second hyperbole in My Sweet Boy poem is in the first line of the last stanza, it is All of Heaven awaits you. In this line, the author is would like to say through this line that she believe God will put the victim to His heaven. The God's heaven will wait for victim after his tragic dead.

This line is also include into hyperbole of figurative language, because as human we do not know about the God's heaven, we do not know that all of the victim will wait by heaven. Eventhough we believe but we can not prove it for real.

3.2 Figurative language convey the social values in Black Live Matter poems

Peter (2002:12) said that figurative language is a language which has figurative meaning and incorporates the speaker's desire to touch the emotion, to cause shock and to persuade into action.

Based on Peter's opinion above, the writer concludes that there are some purpose of the author when he/she set some figurative language in his/her poem, one of them is figurative language use to convey social values through each figurative language meaning for all of the poem readers. Wellek and Warren (1989: 109) also said that literature as a social institution that uses the medium of language, in conveying messages is channeled in the form of symbolism in the form of conventions and social norms.

After analyze 19 data of figurative language based on three poems above and understanding one by one the meaning of them, here the writer present some tables of social values in each poem.

TABLE 1

Mothe Africa, May I return?

\begin{tabular}{|c|c|c|}
\hline $\mathbf{0}$ & $\begin{array}{l}\text { SOCIAL } \\
\text { VALUES }\end{array}$ & DATA \\
\hline & $\begin{array}{l}\text { Mutual } \\
\text { Cooperation }\end{array}$ & - \\
\hline & Unity & - \\
\hline & Humanity & $\begin{array}{l}\text { I'm shouting } \\
\text { out to you as my } \\
\text { universe falls. } \\
-\quad \text { These chains } \\
\text { on my neck and hands } \\
\text { are hurting. } \\
\text { - Lost. In the } \\
\text { dark. I can not see. } \\
\text { - For yet, I will } \\
\text { be sold as a slave. } \\
\text { - Will you } \\
\text { welcome me with } \\
\text { open arms? } \\
\text { - I see other } \\
\text { people chained just } \\
\text { like me. }\end{array}$ \\
\hline & Loyalty & $\begin{array}{l}\text { - Over } 500 \\
\text { years past, I still call } \\
\text { for you. } \\
\text { - Why have you } \\
\text { stopped looking for } \\
\text { me? Mother } \\
\text { - Africa, Are you still } \\
\text { Afriting for me. } \\
\text { waiting } \\
\text { - Mother } \\
\text { Africa, can you hear } \\
\text { my calls? }\end{array}$ \\
\hline & Responsibility & - \\
\hline
\end{tabular}

TABLE II

Dear Emmet Till

\begin{tabular}{|l|l|l|}
\hline o & \multicolumn{1}{|c|}{ SOCIAL } & DATA \\
\hline & $\begin{array}{l}\text { Vutual } \\
\text { Cooperation }\end{array}$ & - \\
\hline
\end{tabular}


Dedi Efendi

Jurnal JILP (Jurnal Ilmiah Langue and Parole) Vol. 4 No. 2 (2021) ISSN : 2581-0804

\begin{tabular}{|c|c|}
\hline Unity & $\begin{array}{l}\text { - and befriends } \\
\text { the night, } \\
\text { kisses the sun and }\end{array}$ \\
\hline Humanity & $\begin{array}{l}\text { - that got you } \\
\text { killed, face beaten } \\
\text { in like a castrated } \\
\text { mummy. } \\
\text { - Blood stains } \\
\text { the Coliseum doors. } \\
\text { - We no longer } \\
\text { wear those chains } \\
\text { just to be painted } \\
\text { gold. A nigga like } \\
\text { - Ang had to } \\
\text { myself had } \\
\text { strong arm a hoe. }\end{array}$ \\
\hline Loyalty & - \\
\hline Responsibility & - \\
\hline
\end{tabular}

TABLE III

My Sweet Boy

\begin{tabular}{|c|c|c|}
\hline о & $\begin{array}{l}\text { SOCIAL } \\
\text { VALUES }\end{array}$ & DATA \\
\hline & Mutual Cooperation & - \\
\hline & Unity & - \\
\hline & Humanity & $\begin{array}{l}- \text { Momma, } \\
\text { Momma } \\
\text { Send the angels } \\
-\quad \text { All of } \\
\text { Heaven awaits you }\end{array}$ \\
\hline & Loyalty & - \\
\hline & $\begin{array}{l}\text { y } \\
\text { y }\end{array}$ & - \\
\hline
\end{tabular}

From three tables above, can be explain that in these three poems of Black Lives Matter community, we can see and conclude that social values of humanity is more dominant in these three poems. Every single figurative language that mention by the author in his/her poem is react about bad treatment, unfairly and racism by Unites State of America regarding humanity. For example, in line 3 of Mother Africa, May I return? poem These chains on my neck and hands are hurting. In this line, the author really feels that there is no good humanity treatment that they got when some chains set in her neck and her hands. The author gives an illustrate some chains set on the balck people's neck and hands as brutality of their government.

The next example of social value of humanity can be seen on Lost in the dark. I can not see, For yet, I will be sold as a slave. In these lines the author would like to says that the black people in America did not get any good occupation, but when they got some jobs they got lowest salary from the company, so in this poem the author compare they low salary with their hard work look like a slave.

Another example of bad humanity treatment that black people got is can be seen in the second line of the second poem in the research Dear Emmet Till poem, it is that got you killed, face beaten in like a castrated mummy. In this line, the author explain that how cruel of the murderers did to the victim Emmet Louis Till. They did just like castrated mummy to their victim.

The second dominant social value in these three poem is about loyalty. The author would like to says that because of unfairness, racism and bad treatment that they got from the government make the black people feel that they can't be loyalty to his country, they do not feel safe in this country, they do not get what should they got (their right). For example of this case is can be seen in line 3 of the fourth stanza of Mother Africa, May I return? poem, it is Over 500 years past, I still call for you. In this line, the author would like to explain that eventhough they live in America but they have a plan to move back to their ancestor country Africa since along time ago. 


\section{CONCLUSION}

After Analyzing the data, the writer explains the summary or the result of this research. It contain the kinds of figurative language and social values that found in these three poems of Black Live Matter (BLM) community. Black Lives Matter (BLM) is a movement organization for black people community in the United States of America. BLM is an organization advocating for nonviolent civil disobedience in protest against incidents of police brutality against AfricanAmerican people. In BLM activities, they (BLM proponents) use some ways to convey their protest for any kinds of unfairly, racism and bad treatment that they got, one of them is they create some poems and put some figurative languages in the poems.

In this research, the writer found about 19 data to explain as the sample for the research. All of the data analyzed in those three poems of Black Live Matter's community. The writer found about only four kinds figurative language in those poem, they are; personification, hyperbole, simile and symbol. From four figurative languages which writer analyzed, hyperbole is the dominant figurative language in all of the poems created by the authors because hyperbole is the appropriate of figurative language for BLM's proponents for looking for help. There are 8 figurative language of the poems about hyperbole in these three poems. The second dominant figurative language in the poems are personification and simile, there are 4 figurative languages found for each kind. And the last figurative language found by the writer in those three poems is symbol. There are 3 figurative language that categorize as symbol in all of data. But, in otherwise symbol is the rarely figurative language found in these poems due to BLM's proponents just focus on their one symbol, it is their hastag \#blacklivesmatter

Then, another important poin in this research is all of the peoms convey some social values through the 19 data of those figurative languages. The dominant social value in the poems is about humanity. Humanity is one of the biggest issue for black people in United State of America. From 19 data, humanity is the dominant data then follows by loyalty, because the black people in America got bad treatment from their own government and they have been suffer for long time. The authors would like to say that how important humanity value in our daily life is. Social values of mutual cooperation and responsibility were not found yet in the poems. The social values that writer found in the poems are; humanity, loyalty and unity. 


\section{Bibliography}

[1]Abrams. M. H. (1999). A Glossary of [10]Klerer, Mario. (2004). An Introduction to Literatureterm. Seventh Ewdition. New York: Early Mcpeek.

[2]Aristotle. (1982). On Poetry and Style, BobbsMerril Educational Publishing Indianapolis, Toronto. Literary Studies. London: Routesge.

[11]Nuraeni, Anis. (2017) Figurative Language in the Poems of Jalaluddin Rumi: A Socioliguistic Perspective, Surakarta: UMY Surakarta.

[3]Barnet, Silvan et, al., (1961). An Introduction [12]Perrine, Laurence, and Thomas R. ARP, to Literature, United State of America.

[4]Barnet, Silvan. (1968). A Short Guide to Writing About Literature, Little, Brown and[1] Company, Boston.

[5]Bodgan, R.C and Biklen, S.K. (1982). Qualitative Research for Education. Boston: Allyn and Bacon, Inc.

[6]Efendi, Dedi. (2010). Figure of Speech Analysis on Three Poems John Donne (Hymn to God My God in My Sickness, A Hymn to God the Father and Death be Not Proud), UIN Jakarta: Krinok, Junrnal Linguistik Budaya. (1992) Sound and Sense; An Introduction to Poetry, 8th edition, Southern Methodist University.

[13]Strauss, A. And Corbin, J. (1998). Basic of Qualitative Research: Second Edition: Techniques and Procedures for Developing Grounded Theory. California: SAGE Publication, Inc.

[14]Amir in Sukatman. (1992). Nilai-nilai Kultural Edukatif dalam Peribahasa Indonesia. Tesis. S2 yang tidak dipublikasikan. Malang: IKIP Program Pasca Sarjana.

[7]Gill, Rechard (1995). Mastering English [15]Teeuw, A. (2003) Sastra dan Ilmu Sastra, Literature, New York: Macmillan Press Ltd.

[8]Iryanti, Fitri. (2010) A Figurative Language Analysis on Sylvia Plath Poem, Jakarta: UIN Jakarta. Jakarta: Pustaka Jaya,

[16]Vanderstoep, S. W. And Johnston, D. (2009) Research Methods for Everyday Life: Blending Qualitative and Quantitative Approach. San Fransisco: Wiley \& Sons.

[9]Johnston, Chris. (1992). What is Social Value. [17]Wellek, Rene and Austin Werren (1997). Canberra: Australian Government Publishing Service. Theory of Literature. New York: Harvest Book; Harcourt, Brace and World. Inc. 